\title{
Effect of 2-Fluorohistidine Labeling of the Anthrax Protective Antigen on Stability, Pore Formation, and Translocation ${ }^{\dagger}$
}

\author{
D. Shyamali Wimalasena, ${ }^{\ddagger}$ John C. Cramer, ${ }^{\S}$ Blythe E. Janowiak,, Stephen J. Juris, ${ }^{I I, \# ~ R o m a n ~ A . ~ M e l n y k, ~}{ }^{I l,}$ \\ D. Eric Anderson, ${ }^{\perp}$ Kenneth L. Kirk, ${ }^{\S}$ R. John Collier," and James G. Bann*, \\ Department of Chemistry, Wichita State University, Wichita, Kansas 67260-0051, Laboratory of Bioorganic Chemistry, and \\ Proteomics and Mass Spectrometry Facility, National Institute of Diabetes and Digestive and Kidney Diseases, \\ National Institutes of Health, Bethesda, Maryland 20892-0810, and Department of Microbiology and \\ Molecular Genetics, Harvard Medical School, Boston, Massachusetts 02115
}

Received August 29, 2007; Revised Manuscript Received October 10, 2007

\begin{abstract}
The action of anthrax toxin relies in part upon the ability of the protective antigen (PA) moiety to form a heptameric pore in the endosomal membrane, providing a portal for entry of the enzymic moieties of the toxin into the cytosol. Pore formation is dependent on a conformational change in the heptameric prepore that occurs in the neutral to mildly acidic $\mathrm{pH}$ range, and it has been hypothesized that protonation of one or more histidine residues triggers this transition. To test this hypothesis, we used biosynthetic methods to incorporate the unnatural amino acid analogue 2-fluorohistidine (2-FHis) into PA. 2-FHis is isosteric with histidine but resists protonation at physiological $\mathrm{pH}$ values due to a dramatically reduced side-chain $\mathrm{p} K_{\mathrm{a}}(\sim 1)$. We found that 2-FHis-labeled PA was biologically inactive, as judged by its inability to deliver a model intracellular effector, $\mathrm{LF}_{\mathrm{N}}-\mathrm{DTA}$, to the cytosol of $\mathrm{CHO}-\mathrm{K} 1$ cells. However, whereas 2-FHis blocked a conformational transition in the full-length $\mathrm{PA}_{83}$ protein in the $\mathrm{pH} 5-6$ range, the $\mathrm{pH}$ dependence of prepore-to-pore conversion of $\left(\mathrm{PA}_{63}\right)_{7}$ was unchanged from the wild-type protein, implying that this conversion is not dependent on His protonation. Consistent with this result, the labeled, trypsinactivated PA was able to permeabilize liposomes to $\mathrm{K}^{+}$and retained pore-forming activity in planar phospholipid bilayers. The pores in planar bilayers were incapable, however, of translocating a model ligand in response to a transmembrane $\mathrm{pH}$ gradient or elevated voltage. The results indicate that protonation of residues other than His, presumably Glu and/or Asp side chains, triggers pore formation in vitro, but His residues are nonetheless important for PA functioning in vivo.
\end{abstract}

Vegetative Bacillus anthracis secretes a toxin that is comprised of a tripartite set of proteins that includes the protective antigen (PA), ${ }^{1}$ edema factor $(\mathrm{EF})$, and lethal factor (LF). The transport of EF and LF into the cell, a process that is critical for the pathogenesis of anthrax, can only occur through a pore formed by the PA (1). PA is a four-domain, $83 \mathrm{kDa}$ protein (Figure 1A) that recognizes on host cells the von Willebrand factor A domains (VWA) of two integrinlike receptors, anthrax toxin receptors 1 and 2 (ANTXR1

\footnotetext{
$\doteqdot$ This work supported by NIH U54 AI057160 to the Midwest Regional Center of Excellence for Biodefense and Emerging and Infectious Disease Research (MRCE), an NIH IDEA/COBRE-PSF award through the University of Kansas (J.G.B.), and by NIH Grant AI22021 (R.J.C.). Research at NIH (K.L.K., J.C.C., and D.E.A.) was supported by the intramural research funds of NIDDK.

* To whom correspondence should be addressed. Phone: 316-9787373. Fax: 316-978-3431. E-mail: Jim.Bann@wichita.edu.

$\doteqdot$ Wichita State University.

${ }^{\S}$ Laboratory of Bioorganic Chemistry, National Institute of Diabetes and Digestive and Kidney Diseases.

${ }^{\perp}$ Proteomics and Mass Spectrometry Facility, National Institute of Diabetes and Digestive and Kidney Diseases.

"Harvard Medical School.

\# Current address: Departments of Biology and Chemistry, Central Michigan University, Mount Pleasant, MI, 48859.

${ }^{£}$ Current address: Merck Research Laboratories, Merck Frosst Canada \& Co., Inc., Department of Biochemistry, Office 10-3-220, 16711 TransCanada Highway, Kirkland QC, Canada H9H 3L1.
}

and ANTXR2) (2-4). Binding of PA to the host cell receptor leads to the proteolytic cleavage of PA by a furin-like protease on the cell surface, releasing the first 167 amino acid residues of domain 1 . This processing event is followed by oligomerization of the remaining cell-bound $63 \mathrm{kDa}$ segment into a donut-shaped heptameric structure called the prepore (5). The formation of the prepore creates binding sites for EF and LF, which bind with a stoichiometry of 3 per heptameric prepore $(6,7)$. The toxin is then internalized into an early endosome, which is trafficked to a late

\footnotetext{
${ }^{1}$ Abbreviations: Ala, alanine; ANTXR2, anthrax toxin receptor 2 (formerly CMG2, capillary morphogenesis protein 2); ANTXR1, anthrax toxin receptor 1 (formerly ATR-TEM8, anthrax toxin receptortumor endothelial marker 8); Asn, asparagine; Asp, aspartate; BisTris, bis(2-hydroxyethyl)amino-tris(hydroxymethyl)methane; $\mathrm{CD}$, circular dichroism; DPhPC, 1,2-diphytanoyl-sn-glycerol-3-phosphocholine; DOPC, 1,2-dioleoyl-sn-glycero-3-phosphocholine; EF, edema factor; 2-FHis, 2-fluorohistidine; Glu, glutamate; HEPES, $N$-(2-hydroxyethyl)piperazine- $N$-(2-ethane sulfonic acid); IPTG, isopropyl- $\beta$-D-thiogalactopyranoside; $\mathrm{K}^{+}$, potassium ions; $\mathrm{LF}$, lethal factor; $\mathrm{LF}_{\mathrm{N}}$, residues $1-263$ of lethal factor; $\mathrm{LF}_{\mathrm{N}-\mathrm{DTA}}$, fusion of $\mathrm{LF}_{\mathrm{N}}$ and the catalytic domain of diphtheria toxin; Lys, lysine; MIDAS, metal ion-dependent adhesion site; $\mathrm{N}$, native folded state; I, intermediate folded state; U, unfolded state; $\mathrm{PA}$, protective antigen; $\mathrm{PA}_{83}$, protective antigen precursor; $\mathrm{PA}_{63}$, a single monomer of the heptamer of protective antigen; $\left(\mathrm{PA}_{63}\right)_{7}$, the heptameric form of the protective antigen; PCR, polymerase chain reaction; Phe, phenylalanine; VWA, the von Willebrand factor A domain of ANTXR2; WT, wild-type.
} 
A
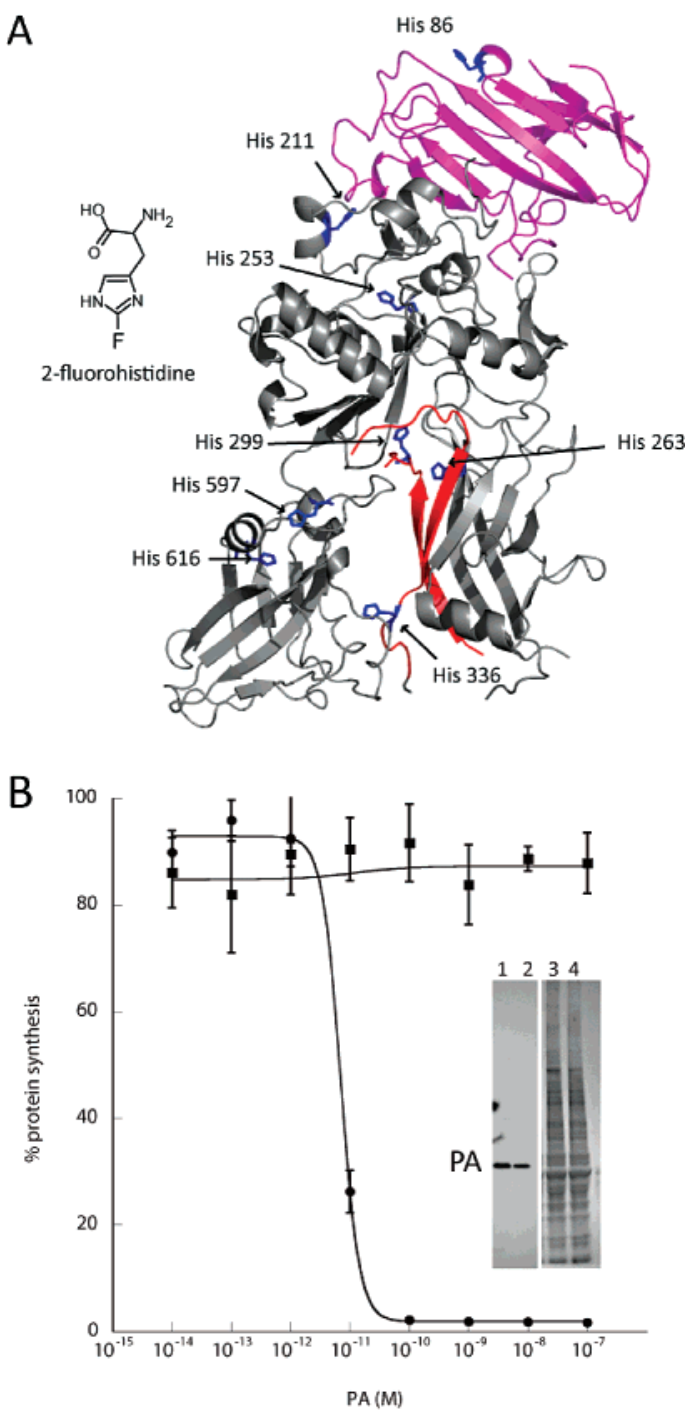

Figure 1: (A) Structure of WT PA 83 (gray) (PDB: 1ACC) (36). Eight of the 10 histidine residues are shown (blue sticks). The domain $2 \beta 2-\beta 3$ strands that form part of the transmembrane pore are shown in red (residues 288-340). The $\mathrm{PA}_{20}$ domain that is cleaved off upon cell binding is shown in magenta. The figure was generated using the program Pymol v. 0.97 (http//www.pymol.org). 2-Fluorohistidine is shown in the inset. (B) Cytotoxicity as determined by protein synthesis inhibition after addition of WT $\mathrm{PA}_{83}(-)$ or 2 -FHisPA 83 (ם) proteins and $\mathrm{LF}_{\mathrm{N}-\mathrm{DTA}}$ to $\mathrm{CHO}-\mathrm{K} 1$ cells. Plotted are averages of $\geq 3$ experiments with error bars showing the standard deviation. Lines shown are data fitted to a standard $\mathrm{EC}_{50}$ equation. Inset: left panel is the autoradiogram from a Western blot of an SDS-PAGE of the cell lysate (right panel) of CHO-K1 cells incubated with either $5 \mu \mathrm{g}$ WT PA 83 (lanes 1 and 3 ) or 2-FHisPA 83 (lanes 2 and 4), as indicated, and probed using an anti-PA antibody.

endosome that eventually becomes acidified $(8,9)$. Acidification within the vesicle to a $\mathrm{pH}$ of $\sim 5-6$ causes a large structural change in which residues 285-340 peel away from the core of domain 2 and form part of a 14-stranded transmembrane extended $\beta$-barrel, called the pore (10-12). In this state, EF and LF can translocate through the pore into the cytosol, which, through manifestation of their enzymatic functions, ultimately results in cellular toxicity.

The conformational change from a prepore to a pore can occur in vitro at a $\mathrm{pH} \leq 7(5,12,13)$ and is at a $\mathrm{pH}$ near the histidine $\mathrm{p} K_{\mathrm{a}}$ (the $\mathrm{p} K_{\mathrm{a}}$ of histidines can vary widely, but in general is around $\mathrm{pH} 6(14,15))$. On the basis of these experiments, and on the recent crystal structures of ANTXR2 bound to either $\mathrm{PA}_{83}(16)$ or the heptameric prepore $\left(\mathrm{PA}_{63}\right)_{7}$ (5), the current hypothesis is that the $\mathrm{pH}$-dependent structural changes that lead to pore formation are a result of the protonation of histidine residues (13). There are a total of 10 histidines in $\mathrm{PA}_{83}$ (Figure 1A), and 4 of the 5 histidine residues in domain 2 are part of the $\beta$-barrel that comprises the pore $(10)$. In the present study, we report the effects of the uniform incorporation of the unnatural amino acid 2-fluorohistidine (2-FHis-Figure 1A, inset) on the structure of $\mathrm{PA}_{83}$ and on the structure and functional aspects of the heptameric prepore $\left(\mathrm{PA}_{63}\right)_{7}$ and pore, respectively. This unnatural amino acid is isosteric with histidine, but the sidechain $\mathrm{p} K_{\mathrm{a}}$ is lowered to $\sim 1$, due to the electron-withdrawing inductive effect of the fluorine $(17-20)$. The results presented herein indicate that histidine protonation is not a requirement for the in vitro formation of pores but may have a role in translocation or on the ability to form pores in vivo.

\section{MATERIALS AND METHODS}

Reagents, Plasmids, Strains. All buffers for purification and analysis were either from Sigma or Fisher Scientific and were reagent grade. Synthesis of 2-FHis was performed as described previously $(18-20)$. The histidine auxotroph UTH780 was obtained from the E. coli Genetic Stock Center at Yale University (New Haven, CT). The protective antigen gene in pET22b $(+)(21)$, which is under a T7 promoter, was moved to the plasmid pQE80 (Qiagen) by first removing the EcoR1 site in the protective antigen gene using the Quikchange mutagenesis kit (Stratagene) with primers (5'GCAGGATTTAGTAATTCGAACTCAAGTACGGTCGC$3^{\prime}$ and 5'-GCGACCGTACTTGAGTTCGAATTACTAAATCCTGC-3' (Sigma Genosys) that directed a silent change from GAATTC $(A A T=A s n)$ to GAACTC $(A A C=A s n)$ and then using PCR to clone the full-length $\mathrm{PA}_{83}$ gene (including the phoA signal sequence from pET22b(+)) as an EcoR1/ KpnI fragment into pQE80 (forward primer, 5' CCCGAATTCATTAAAGAGGAGAAATTAACTATGAAATACCTGCTGCCGAC C-3'; reverse primer, 5' GGGGGTACCTCAGCTAATTATCCTATCTCATAG-3'). Sequences were verified by the Protein and Nucleic Acid Chemistry Laboratory (PNACL) at Washington University (St. Louis, MO).

Labeling with 2-FHis. UTH780 cells were transformed with the $\mathrm{pQE} 80-\mathrm{PA}_{83}$ plasmid and were grown in the presence of $100 \mu \mathrm{g} / \mathrm{mL}$ ampicillin. The medium for growth was a modified version of the ECPM1 media (21) but with defined amino acids (22) and glucose $(0.5 \%)$ instead of NZ amine, yeast extract, and glycerol. The cells were grown to an $A_{600}$ of 3 in Fernbach shaker flasks at $32{ }^{\circ} \mathrm{C}$. The cells were then washed twice with $0.9 \% \mathrm{NaCl}$, and then the same media containing $0.2 \mathrm{mM}$ 2-FHis in place of histidine $(0.2$ $\mathrm{mM}$ ) was added to the cells and resuspended. The cells were then incubated for $10-15$ min with shaking prior to the addition of IPTG to $1 \mathrm{mM}$ (22). After growth at $26^{\circ} \mathrm{C}$ for $3 \mathrm{~h}$, the cells were harvested in a centrifuge equipped with a swinging bucket rotor $(3000 \mathrm{~g})$ for $10 \mathrm{~min}$ and then placed on ice for purification.

Purification of $\mathrm{PA}_{83}$ Proteins. Cells were resuspended in $500 \mathrm{~mL}$ of $20 \mathrm{mM}$ Tris $-\mathrm{HCl}, \mathrm{pH} 8,20 \%$ sucrose, and 1 $\mathrm{mM}$ EDTA, and incubated for $15 \mathrm{~min}$ at room temperature with gentle stirring. The cells were centrifuged for $15 \mathrm{~min}$ 
at $4{ }^{\circ} \mathrm{C}(8000 \mathrm{~g})$, the supernatant was removed, and cells were resuspended in ice-cold $5 \mathrm{mM} \mathrm{MgSO}_{4}$ and stirred for 15 min at $4{ }^{\circ} \mathrm{C}$. After the addition of $1 \mathrm{M}$ Tris $-\mathrm{HCl} \mathrm{pH} 8.0$ to a final concentration of $20 \mathrm{mM}$, the cells were centrifuged again at $4{ }^{\circ} \mathrm{C}(8000 \mathrm{~g})$. The supernatant was removed and applied to a Hi-Trap Q anion exchange column (GEHealthcare) equilibrated in $20 \mathrm{mM}$ Tris $-\mathrm{HCl}, \mathrm{pH} 8.0\left(4^{\circ} \mathrm{C}\right)$ and eluted with a $\mathrm{NaCl}$ gradient on an AktaPrime LC (GEHealthcare). Fractions were pooled, concentrated using an Amicon Ultra-15 $10 \mathrm{kDa}$ cutoff centrifugal filter (Millipore), and then applied to a Sephadex S-200 gel filtration column (GE-Healthcare) equilibrated in $20 \mathrm{mM}$ Tris $-\mathrm{HCl}, 150 \mathrm{mM}$ $\mathrm{NaCl}, \mathrm{pH} 8.0\left(4^{\circ} \mathrm{C}\right)$. Fractions containing pure protein were identified using SDS-PAGE, pooled, and concentrated. Protein concentration was determined using a calculated extinction coefficient of $80220 \mathrm{M}^{-1} \mathrm{~cm}^{-1}$ (23).

Trypsin Cleavage of Protective Antigen. Conversion of $\mathrm{PA}_{83}$ and 2-FHisPA 83 to the heptameric prepore $\left(\mathrm{PA}_{63}\right)_{7}$ and $\left(2-\mathrm{FHisPA}_{63}\right)_{7}$, respectively, was performed at room temperature for $30 \mathrm{~min}$ by the addition of trypsin (Trypzean, Sigma-Aldrich) with a ratio of $1 \mu \mathrm{g}$ of trypsin to $1 \mathrm{mg}$ of $\mathrm{PA}_{83}$, followed by the addition of a 10 -fold excess of soybean trypsin inhibitor. Trypsin-activated PA was then loaded onto a Hi-Trap Q column equilibrated in $20 \mathrm{mM}$ Tris, $\mathrm{pH} 8.5$, and $\left(\mathrm{PA}_{63}\right)_{7}$ or $\left(2-\mathrm{FHisPA}_{63}\right)_{7}$ was purified using a $\mathrm{NaCl}$ gradient (21). Final purification was accomplished by applying the preparation to a Sephadex S-200 gel filtration column (GE-Healthcare) equilibrated in $20 \mathrm{mM}$ Tris $-\mathrm{HCl}$, $400 \mathrm{mM} \mathrm{NaCl}, \mathrm{pH} 8.5$.

Protein Synthesis Experiments in CHO-K1 Cells. Translocation studies in CHO-K1 cells were conducted in 96-well microtiter plates $(31,32)$. CHO-K1 cells were incubated with WT or 2-FHisPA ${ }_{83}$ in the presence of $\mathrm{LF}_{\mathrm{N}}$ fused with the catalytic subunit of diphtheria toxin $\left(\mathrm{LF}_{\mathrm{N}-} \mathrm{DTA}\right)$ for $4 \mathrm{~h}$ at $37{ }^{\circ} \mathrm{C}$. Medium was removed and replaced with leucinefree HAM F-12 medium supplemented with ${ }^{3} \mathrm{H}$-leucine. After incubation for $1 \mathrm{~h}$ at $37^{\circ} \mathrm{C}$, cells were washed with PBS and then incubated with ice-cold $10 \%$ trichloroacetic acid. The ability of DTA to block protein synthesis was quantified by measuring the amount of ${ }^{3} \mathrm{H}$-leucine present in the TCA precipitate. The amount incorporated in the absence of $\mathrm{PA}_{83}$ (and thus no diphtheria toxin could make it into the cells) was compared to that in the presence of either WT or 2-FHisPA 83 .

LC/ESI-MS Analysis. Protein samples were desalted on a $1.5 \mathrm{~cm} \times 1 \mathrm{~mm}$ i.d. column hand-packed with Zorbax SBC8, $5 \mu \mathrm{m}$ (Agilent Technologies, Wilmington, DE). A linear gradient was developed by the Ultra-Plus II (Micro-Tech Scientific, Vista, CA) using aqueous $0.1 \%$ TFA as mobile phase A and 2-propanol/acetonitrile/water/TFA 80/10/9.9/ $0.1(\mathrm{v} / \mathrm{v} / \mathrm{v} / \mathrm{v})$ as mobile phase B. Proteins were directly eluted into the ESI (electrospray ionization) source of a Finnigan LTQ-FT hybrid linear quadrupole ion trap Fourier transform ion cyclotron resonance (FT-ICR) mass spectrometer (ThermoElectron, Bremen, Germany). Calibration of the instrument was performed biweekly with caffeine (Sigma), MRFA (tetrapeptide, Thermo-Electron), Ultramark 1621 (perfluoroalkylphosphazine, Lancaster) in the mass range of 195$2000 \mathrm{u}$. Spectra were acquired in positive mode over the $\mathrm{m} / \mathrm{z}$ mass range of 500-2000 with the FT-ICR operated at resolution (50 000) using an automated gain control (AGC) value of 50000 or a maximum ion accumulation time of
$3000 \mathrm{~ms}$. The ESI source was operated with spray voltage of $4 \mathrm{kV}$, a tube lens offset of $115 \mathrm{~V}$, and a capillary temperature of $200{ }^{\circ} \mathrm{C}$. All other source parameters were optimized for maximum sensitivity of most abundant multiply charged ions of lysozyme. Spectra were smoothed and deconvoluted using ProMass for Xcalibur, version 2.5 SR-1.

ESI-MS Fragmentation Analysis. Two vials containing 100 pmol of either $\mathrm{PA}_{83}$ or 2-FHisPA 83 were diluted with $50 \mathrm{mM}$ ammonium bicarbonate, $100 \mu \mathrm{L}$ of $0.1 \%$ Rapigest (an acidlabile detergent-Waters Corp.) to which was added either trypsin (Promega) or Lys-C (Roche) at a ratio of 50:1 (by mass). After overnight incubation at $37^{\circ} \mathrm{C}$, the samples were acidified to approximately $\mathrm{pH} 2$ (5\% formic acid) and incubated for $2 \mathrm{~h}$ to decompose the detergent. The sample was centrifuged at $15000 \mathrm{~g}$ for $30 \mathrm{~min}$. Part of this sample was then withdrawn avoiding the top layer of solution and placed in another vial and centrifuged again for $30 \mathrm{~min}$, and the sample below the meniscus was used for analysis on a Micromass QTOF-2 orthogonal acceleration mass spectrometer (Micromass, UK Ltd., Manchester, U.K.). The QTOF-2 was interfaced with a NanoAcquity UHPLC system, and peptides generated from the tryptic digest were separated using linear gradients (A, 0.1\% TFA/water; B, 0.1\% TFA/ acetonitrile) on an analytical C18 column. Fragmentation analysis was carried out on the peptide TFLSPWISNIHEK (residues 201-213). The signal intensities of the 213.13 fragment (b2) were summed for the +2 charge state of both the WT and 2-FHis-containing peptide.

Urea Gradient Gel Electrophoresis. Urea gradient gels were prepared according to the protocol of Goldenberg (28). Urea gradient gels were prerun for $30 \mathrm{~min}$ at a constant current of $20 \mathrm{~mA}$. Samples $(25 \mu \mathrm{g}$ in $75 \mu \mathrm{L})$ were applied to the top of the gels, and gels were run for $16 \mathrm{~h}$ at $20^{\circ} \mathrm{C}$, $20 \mathrm{~mA}$.

Fluorescence. Fluorescence spectra of $\mathrm{WT}^{\mathrm{PA}_{83}}$ and 2-FHisPA ${ }_{83}$ were acquired on a Cary Eclipse spectrofluorometer. All experiments were done at $20{ }^{\circ} \mathrm{C}$, and the concentrations were kept at an $A_{280}$ of $0.01(\sim 0.1 \mu \mathrm{M})$ in 10 $\mathrm{mM}$ HEPES (sodium salt)/BisTris/cacodylic acid $\mathrm{pH} 8.0$ containing urea. Urea concentrations were determined by measuring the refractive index (25). Spectra represent the mean of 10 scans. Emission spectra were recorded with an excitation wavelength of 280 or $295 \mathrm{~nm}$ (10 nm slit width) with $5 \mathrm{~nm}$ slit width for the emission scan $(305-600 \mathrm{~nm})$. Urea denaturation data were fit to a three-state stability equation (native (N) $\leftrightarrow$ intermediate (I) $\leftrightarrow$ unfolded (U)) $(26,27)$, where the equilibrium constants $K_{\mathrm{N} \rightarrow \mathrm{I}}$ and $K_{\mathrm{I} \rightarrow \mathrm{U}}$ are

$$
\begin{aligned}
& K_{\mathrm{N} \rightarrow \mathrm{I}}=\exp \left(-\Delta{G^{\circ}}_{\mathrm{N} \rightarrow \mathrm{I}}-m[\mathrm{D}]\right) / R T \\
& K_{\mathrm{I} \rightarrow \mathrm{U}}=\exp \left(-\Delta{G^{\circ} \rightarrow \mathrm{U}}^{\circ}-m[\mathrm{D}]\right) / R T
\end{aligned}
$$

$\mathrm{D}$ is the denaturant concentration, $R$ is the universal gas constant, and $T$ is temperature in Kelvin.

Assuming that only $\mathrm{N}$, I, and $\mathrm{U}$ are populated during unfolding, then the fractional population of each species in solution during the titration can be represented by

$$
\mathrm{Fl}_{(\mathrm{obs})}=\mathrm{Fl}_{\mathrm{N}} f_{\mathrm{N}}+\mathrm{Fl}_{\mathrm{I}} f_{\mathrm{I}}+\mathrm{Fl}_{\mathrm{U}} f_{\mathrm{U}}
$$




$$
\begin{aligned}
\mathrm{Fl}_{\text {(obs) }}=\left(\mathrm{Fl}_{\mathrm{N}}-\mathrm{Fl}_{\mathrm{I}} K_{\mathrm{N} \rightarrow \mathrm{I}}+\right. & \left.\mathrm{Fl}_{\mathrm{U}} K_{\mathrm{N} \rightarrow \mathrm{I}} K_{\mathrm{I} \rightarrow \mathrm{U}}\right) / \\
& \left(1+K_{\mathrm{N} \rightarrow \mathrm{I}}+K_{\mathrm{N} \rightarrow \mathrm{I}} K_{\mathrm{I} \rightarrow \mathrm{U}}\right)
\end{aligned}
$$

where $f_{\mathrm{N}}, f_{\mathrm{I}}$, and $f_{\mathrm{U}}$ are the fractions of $\mathrm{N}, \mathrm{I}$, and $\mathrm{U}$, respectively. The pre- and post-transition baselines are assumed to be flat. The data were normalized using the equation $y=\mathrm{Fl}_{\text {(obs) }}-\mathrm{Fl}_{\mathrm{U}} / \mathrm{Fl}_{\mathrm{N}}-\mathrm{Fl}_{\mathrm{U}}$. The data were fit by nonlinear least-squares analysis according to eq 4 using Kaleidagraph software. For the $\mathrm{pH}$ studies in Figure 4, measurements by fluorescence were carried out at $0.38 \mu \mathrm{M}$ in a $10 \mathrm{mM}$ BisTris/HEPES/cacodylic acid/citric acid buffer system. Consistent with the observed transitions by urea that allowed us to distinguish the wavelengths for the N, I, and $\mathrm{U}$ states, the $\mathrm{pH}$ transitions were fit using nonlinear leastsquares to the Henderson-Hasselbalch equation, assuming a two-state protonation equilibrium:

$$
\mathrm{Fl}_{(\mathrm{obs})}=\left(\mathrm{Fl}_{(\mathrm{N})}+\mathrm{Fl}_{(\mathrm{I})} 10^{\mathrm{pH}-\mathrm{p} K_{\mathrm{app}}}\right) /\left(1+10^{\mathrm{pH}-\mathrm{p} K_{\text {app }}}\right)
$$

where $\mathrm{p} K_{\mathrm{app}}$ represents an apparent $\mathrm{p} K_{\mathrm{a}}$ encompassing all classes of titratable sites.

Circular Dichroism. Circular dichroism spectra were acquired on a Jasco J-810 spectropolarimeter equipped with a temperature-controlled water bath. Samples of $\mathrm{PA}_{83}$ or 2-FHisPA $83(\sim 10-17 \mu \mathrm{M})$ in $10 \mathrm{mM}$ HEPES (sodium salt)/ BisTris/cacodylic acid at the requisite $\mathrm{pH}$ were placed in a water-cooled $0.1 \mathrm{~mm}$ circular CD cell, and spectra were recorded at $20{ }^{\circ} \mathrm{C}$ from 260 to $180 \mathrm{~nm}$ at a scan rate of 20 $\mathrm{nm} / \mathrm{min}$ and a response time of $4 \mathrm{~s}$. Spectra are the average of five scans. The spectra were recorded after allowing the samples to equilibrate at the respective $\mathrm{pH}$ for at least $24 \mathrm{~h}$. Some visible precipitation of both the WT and 2-FHis-labeled proteins occurred at $\mathrm{pH} \mathrm{5}$, and so these samples were centrifuged for $10 \mathrm{~min}$ on high speed in a microfuge, and the supernatant was used for both concentration determination and generation of the CD spectrum. Data are normalized to the mean residue ellipticity based on a value of 734 peptide bonds. Analyses of the $\mathrm{CD}$ spectra were done using the CDNN program (24).

Prepore-to-Pore Conversion of $\left(\mathrm{PA}_{63}\right)_{7}$ and $\left(2-\mathrm{FHisPA}_{63}\right)_{7}$. The $\mathrm{pH}$-dependent conversion of $\left(\mathrm{PA}_{63}\right)_{7}$ from a prepore to an SDS-resistant state was accomplished by incubating $\left(\mathrm{PA}_{63}\right)_{7}(10 \mu \mathrm{L}$ of $1.2 \mu \mathrm{M}$ in $20 \mathrm{mM}$ Tris $-\mathrm{HCl} \mathrm{pH} \mathrm{8.5,} \mathrm{0.4}$ $\mathrm{M} \mathrm{NaCl}$ ) with $10 \mu \mathrm{L}$ each of $1 \mathrm{M}$ buffers (BisTris, pH 5-6.5 and HEPES, $\mathrm{pH} 7-8$ ) at room temperature for $\sim 1 \mathrm{~h}$. After incubation, $10 \%$ SDS was added to each sample to a final concentration of $1.25 \%$ SDS followed by incubation at room temperature for an additional $20 \mathrm{~min}$ (5). Proteins were then boiled for $5 \mathrm{~min}$ and then applied to a 4-20\% gradient SDS-PAGE gel which was run for $\sim 3.5 \mathrm{~h}$ at constant voltage $(200 \mathrm{~V})$.

Studies of Pore Insertion into Membranes. Membrane insertion of the pores was assayed using the potassium release $\left(\mathrm{K}^{+}\right.$release) assay as previously described (29). Liposomes composed of 1,2-dioleoyl-sn- glycerol-3-phosphocholine (DOPC) were kindly provided by Dr. Jianjun Sun (Harvard Medical School) (29). Immediately prior to performing the $\mathrm{K}^{+}$release assay, the liposomes, maintained in a $\mathrm{K}^{+}$buffer (10 mM HEPES, $100 \mathrm{mM} \mathrm{KCl,} \mathrm{pH} \mathrm{7.4)} \mathrm{were} \mathrm{buffer-}$ exchanged into a $\mathrm{Na}^{+}$buffer $(10 \mathrm{mM}$ HEPES, $100 \mathrm{mM} \mathrm{NaCl}$, $\mathrm{pH}$ 7.4) in order to establish liposomes with $\mathrm{K}^{+}$in the inside
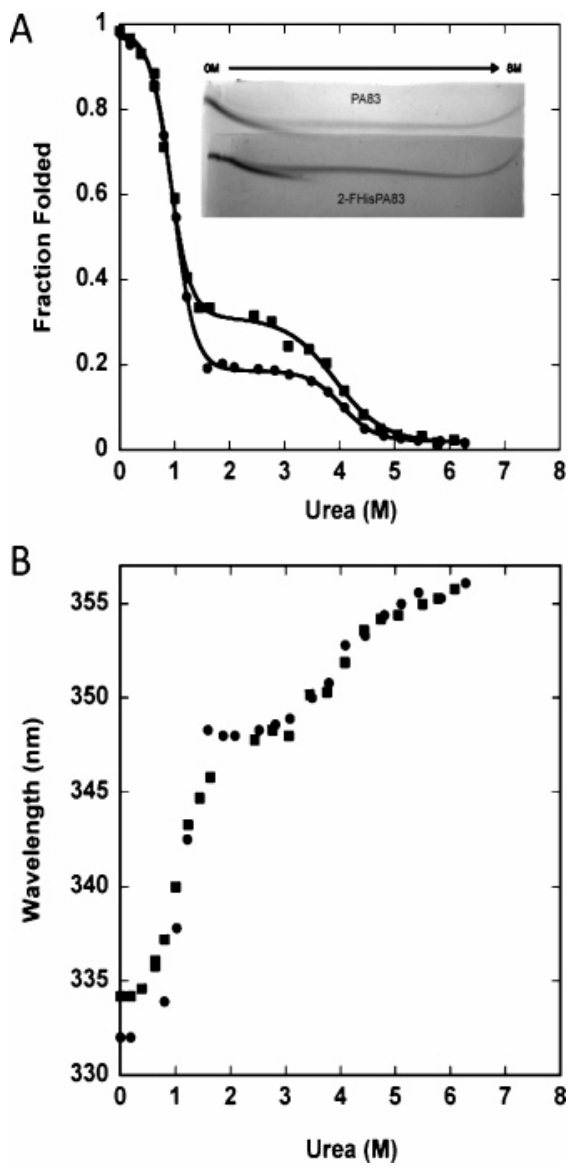

FIGURE 2: Stability of PA and 2-FHis PA to urea. (A) Urea denaturation of WT $\mathrm{PA}_{83}(\mathbf{O})$ and 2-FHis $\mathrm{PA}_{83}(\mathbf{\square})$ were measured using fluorescence and represent the normalized emission intensity at $330 \mathrm{~nm}$ (excitation $280 \mathrm{~nm}$ ). The data were fit using nonlinear least-squares analysis to a three-state $\mathrm{N} \leftrightarrow \mathrm{I} \leftrightarrow \mathrm{U}$ model. Inset: urea gradient gel electrophoresis of $\mathrm{WT} \mathrm{PA}_{83}$ and 2-HisPA $\mathrm{P}_{83}$. Urea gradient gels were prerun for $30 \mathrm{~min}$ at a constant current of 20 mA. Samples ( $25 \mu \mathrm{g}$ in $75 \mu \mathrm{L})$ were applied to the top of the gels, and gels were run for $16 \mathrm{~h}$ at $20^{\circ} \mathrm{C}, 20 \mathrm{~mA}$. (B) Urea denaturation of WT PA $\mathrm{PA}_{83}\left(\mathbf{)}\right.$ and 2-FHis $\mathrm{PA}_{83}(\mathbf{\square})$ as measured in (A), recording the emission wavelength maxima at each urea concentration. All spectra were recorded at $20^{\circ} \mathrm{C}$, in $20 \mathrm{mM}$ BisTris/HEPES/cacodylic acid $\mathrm{pH} 8.0$, and represent the average of 10 scans.

and $\mathrm{Na}^{+}$on the outside. Purified $\left(\mathrm{PA}_{63}\right)_{7}$ or $\left(2-\mathrm{FHisA}_{63}\right)_{7}$ heptamers $(20 \mu \mathrm{g})$ in a buffer kept at $\mathrm{pH} 8.5$ to maintain prepore state were incubated with $150 \mu \mathrm{L}$ of freshly prepared liposomes for $30 \mathrm{~min}$ on ice prior to being diluted into 5 $\mathrm{mL}$ of sodium acetate buffer, $\mathrm{pH} 5.0$, containing $100 \mathrm{mM}$ $\mathrm{NaCl}$. Release of $\mathrm{K}^{+}$from the liposomes was continuously monitored using a $\mathrm{K}^{+}$selective electrode (Orion Research). The control (buffer alone) was subtracted from each experiment to allow comparison between different samples. The buffer-subtracted data from three separate experiments were averaged, and these data were fit to a sum of two exponentials using Kaleidagraph software.

Translocation Studies. Translocation studies were carried out with a planar lipid bilayer system as described previously $(13,30)$. WT $\left(\mathrm{PA}_{63}\right)_{7}$ or $\left(2-\mathrm{FHisPA}_{63}\right)_{7}$ was applied to the cis compartment, and changes in the macroscopic conductance of potassium across a membrane comprised of 3\% 1,2diphytanoyl-sn-glycerol-3-phosphocholine (DPhPC) in $n$ decane (Avanti Polar Lipids, Alabaster, AL) were measured using a planar lipid bilayer workstation (Warner Instruments, Hamden, CT). Once channels started inserting at a faster rate, 
A

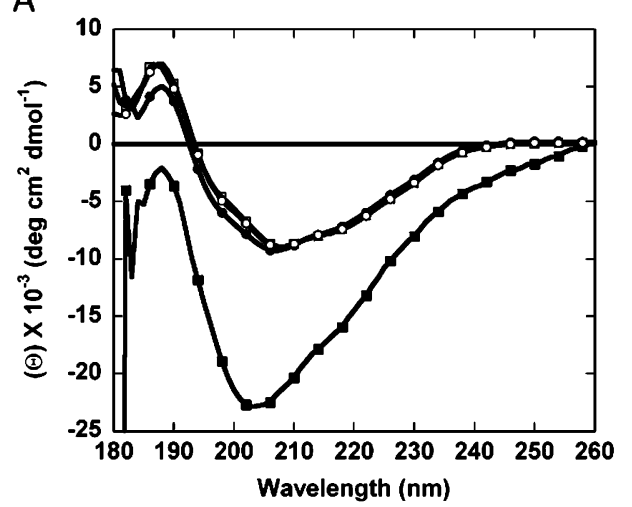

C

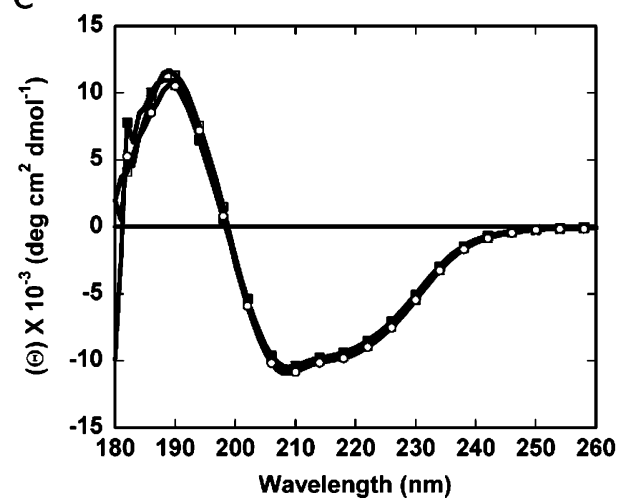

B

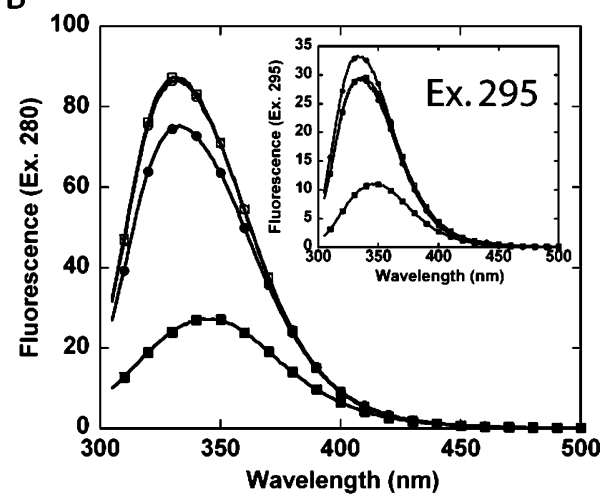

D

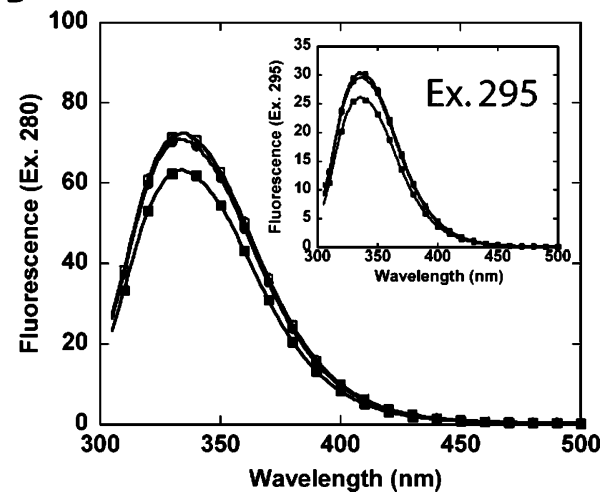

FIGURE 3: Circular dichroism and fluorescence spectra of WT and 2-FHisPA 83 as a function of pH. CD spectra of WT (A) and 2-FHisPA 83 (C) are shown at $\mathrm{pH}$ values of $5(\mathbf{\square}), 6(\bullet), 7(\square), 8(\mathrm{O})$. All spectra were recorded at $20^{\circ} \mathrm{C}$ and represent the average of five scans. Also shown are fluorescence emission spectra of WT (B) and 2-FHisPA ${ }_{83}$ (D) as a function of pH $5(\mathbf{\square}), 6(\bullet), 7(\square), 8(O)$. Spectra were recorded at $20{ }^{\circ} \mathrm{C}$ and represent the average of 10 scans. Spectra were recorded with an excitation wavelength of $280 \mathrm{~nm}$ or with an excitation of $295 \mathrm{~nm}$ (inset).
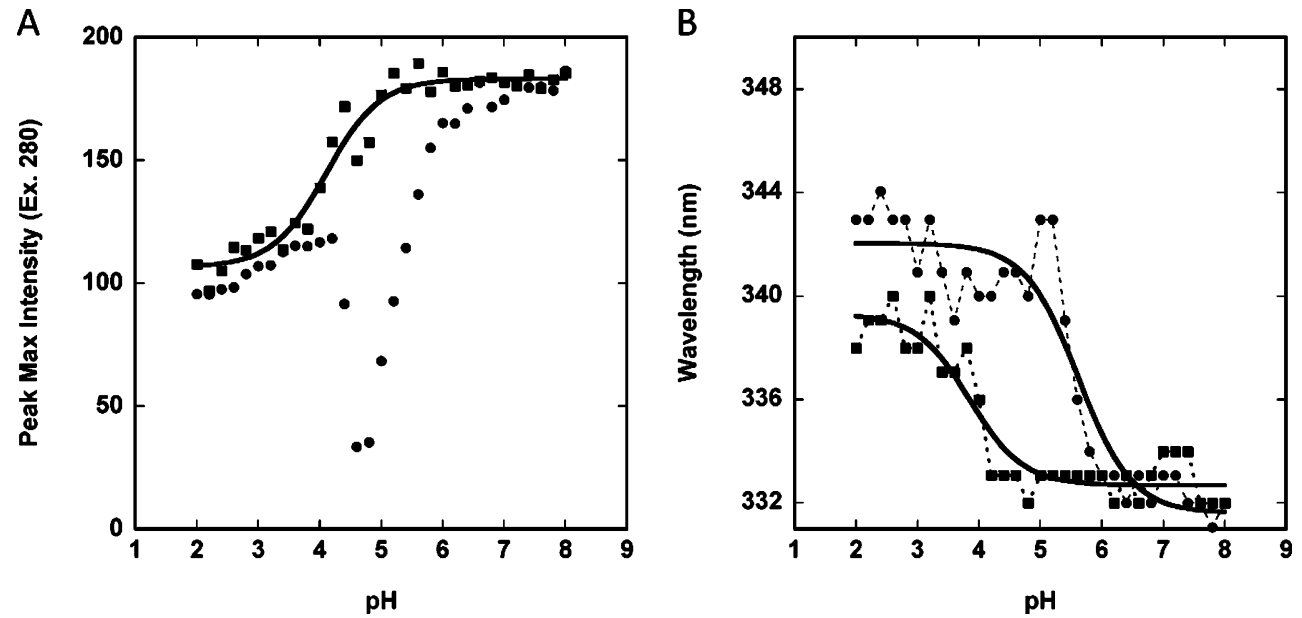

FIGURE 4: Fluorescence total maximum intensity (A) and emission wavelength maximum (B) as a function of pH. All measurements were carried out at $20^{\circ} \mathrm{C}$ in a $10 \mathrm{mM}$ BisTris/HEPES/cacodylic acid/citric acid buffer system. Data for WT (๑) and 2-FHisPA $83(\square)$ are shown. The solid lines through the data points are nonlinear least-squares fits of the data to the Henderson-Hasselbalch equation to give an apparent $\mathrm{p} K_{\mathrm{a}}$ for the $\mathrm{pH}$ transition. To aid in visualization, the data points in (B) are connected with dashed lines.

excess PA was actively removed using a syringe-mediated perfusion system at a rate of $\sim 3 \mathrm{~mL} / \mathrm{min}$. After achieving a stable current, $\mathrm{LF}_{\mathrm{N}}(10 \mathrm{nM})$ was added to the cis compartment, and blockage of channel conductance was measured. Blockage of WT $\left(\mathrm{PA}_{63}\right)_{7}$ is $>95 \%$ in the presence of $10 \mathrm{nM}$ $\mathrm{LF}_{\mathrm{N}}(30)$, and both WT $\left(\mathrm{PA}_{63}\right)_{7}$ and $\left(2-\mathrm{FHisP}_{63}\right)_{7}$ exhibited similar extents of blocking (data not shown). Excess $\mathrm{LF}_{\mathrm{N}}$ was removed by perfusing with $10 \mathrm{~mL}$ of buffer, and then translocation was initiated by increasing $\Delta \Psi$ to $+30 \mathrm{mV}$ or by a change in $\mathrm{pH}$ of the trans compartment to $\mathrm{pH} 7.4$ from
pH 5.5 by the addition of $\mathrm{KOH}(30)$. Data were analyzed using AxographX (AxoGraph Scientific, Sydney, Australia).

\section{RESULTS}

Protein Synthesis Experiments in CHO-K1 Cells. WT PA $\mathrm{P}_{83}$ was labeled with 2-FHis using the bacterial auxotroph UTH780 (17), purified, and found to be $>95 \%$ labeled as evidenced by mass spectrometry (see the Supporting Information). As an initial test of the effect of 2-FHis labeling on the ability of $\mathrm{PA}_{83}$ to function in a manner similar to the 


\begin{tabular}{|c|c|c|c|c|c|c|c|}
\hline & $\mathrm{p} K_{\text {app }}{ }^{a}$ & $\begin{array}{c}\Delta G_{\mathrm{N} \leftrightarrow \mathrm{I}}^{\circ} \\
(\mathrm{kcal} / \mathrm{mol})^{b}\end{array}$ & $\begin{array}{c}\Delta G_{\mathrm{I} \leftrightarrow \mathrm{U}}^{\circ} \\
(\mathrm{kcal} / \mathrm{mol})\end{array}$ & $\begin{array}{c}m_{\mathrm{N} \leftrightarrow \mathrm{I}} \\
\left(\mathrm{kcal} \mathrm{mol} \mathrm{Mo}^{-1} \mathrm{M}^{-1}\right)^{c}\end{array}$ & $\begin{array}{c}m_{\mathrm{I} \leftrightarrow \mathrm{U}} \\
\left(\mathrm{kcal} \mathrm{mol} \mathrm{M}^{-1} \mathrm{M}^{-1}\right)\end{array}$ & $\begin{array}{c}{\left[D_{1 / 2}\right]_{\mathrm{N} \leftrightarrow \mathrm{I}}} \\
(\mathrm{M})^{d}\end{array}$ & $\begin{array}{c}{\left[D_{1 / 2}\right]_{\mathrm{I} \leftrightarrow \mathrm{U}}} \\
(\mathrm{M})\end{array}$ \\
\hline $\mathrm{PA}_{83}$ & $5.9 \pm 0.3$ & $12.5 \pm 1.0$ & $33.2 \pm 2.0$ & $12.8 \pm 0.6$ & $8.1 \pm 1.6$ & $0.98 \pm 0.01$ & $4.10 \pm 0.06$ \\
\hline 2-FHis & $3.6 \pm 0.4 j^{e}$ & $11.7 \pm 1.0$ & $21.8 \pm 1.0$ & $12.9 \pm 1.0$ & $5.5 \pm 1.0$ & $0.91 \pm 0.02$ & $3.96 \pm 0.09$ \\
\hline $\mathrm{PA}_{83}$ & $4.1 \pm 0.1^{f}$ & & & & & & \\
\hline
\end{tabular}

${ }^{a}$ Errors were determined by a best-fit to the Henderson-Hasselbalch equation using nonlinear least-squares analysis in Kaleidagraph. ${ }^{b, c}$ Errors were determined from the fits to a three-state model (26) using nonlinear least-squares in Kaleidagraph. ${ }^{d} D_{1 / 2}=$ midpoint in the urea denaturation curve. ${ }^{e}$ Obtained from the fit to the emission maximum wavelength. ${ }^{f}$ Obtained from the fit to the peak maximum intensity.

\begin{tabular}{|c|c|c|c|c|c|c|c|c|c|}
\hline & $\%$ helix & $\begin{array}{l}\% \beta \text {-sheet } \\
\text { (parallel) }\end{array}$ & $\begin{array}{c}\% \beta \text {-sheet } \\
\text { (antiparallel) }\end{array}$ & $\% \beta$-turn & $\%$ random & $\begin{array}{l}\max \\
(\mathrm{nm})\end{array}$ & $\begin{array}{c}\min (\mathrm{pH} 5) \\
(\mathrm{nm})\end{array}$ & $\min _{(\mathrm{nm})}$ & $\min _{(\mathrm{nm})}$ \\
\hline WT & 13.3 & 3.0 & 31.9 & 21.9 & 33.6 & 187 & 203 & 207 & 219 \\
\hline 2FHis & 19.8 & 4.6 & 20.5 & 20.6 & 31.7 & 189 & & 208.3 & 220.7 \\
\hline actual $^{a}$ & 13.8 & $\mathrm{ND}^{b}$ & 30 & ND & ND & & & & \\
\hline
\end{tabular}

WT protein, we utilized a cytotoxicity assay $(31,32)$. In this assay, WT and 2-FHisPA 83 are added to CHO-K1 cells along with $\mathrm{LF}_{\mathrm{N}}-\mathrm{DTA}$, a fusion of $\mathrm{LF}_{\mathrm{N}}$ and the catalytic domain of diphtheria toxin; if PA is functional, $\mathrm{LF}_{\mathrm{N}}-\mathrm{DTA}$ will be translocated into the cytosol and inhibit protein synthesis (30, 31). CHO-K1 cells contain on their surfaces the ANTXR2 receptor and the furin-like protease to cleave $\mathrm{PA}_{83}$ to $\mathrm{PA}_{20}$ and $\mathrm{PA}_{63}$ (34) and uptake $\left(\mathrm{PA}_{63}\right)_{7}-\mathrm{LF}_{\mathrm{N}}-\mathrm{DTA}$. Protein synthesis was assayed by incorporation of ${ }^{3} \mathrm{H}$-leucine into cells. Labeling with 2-FHisPA ${ }_{83}$ did not affect the ability of $\mathrm{PA}$ to bind to $\mathrm{CHO}-\mathrm{K} 1$ cells (see the inset, Figure 1B) or to the isolated PA binding domain of CMG2 (results not shown). However, in contrast to results with WT PA 83 and $\mathrm{LF}_{\mathrm{N}}-\mathrm{DTA}$, no inhibition of protein synthesis was detected after addition of 2-FHisPA ${ }_{83}$ and $\mathrm{LF}_{\mathrm{N}}-$ DTA (Figure 1B). These data suggest that either histidine protonation is important in one or more steps along the pathway (pore formation, translocation) or that the structural integrity of the protein was compromised by 2-FHis labeling.

Effect of 2-FHis on the Structure of $P A_{83}$ : Equilibrium Stability of 2-FHis and WT $P A_{83}$. Urea gradient gel electrophoresis was used along with fluorescence emission as a function of urea to determine the relative stability of 2-FHisPA ${ }_{83}$ to that of the WT protein, and the data are shown in Figure 2. There are two separate transitions in the fluorescence data, the first from 0 to $\sim 2 \mathrm{M}$ urea, and another from 2 to $6 \mathrm{M}$ urea, indicating the presence of a stable intermediate in the unfolding process $(32,33)$. The first transition (N to $\mathrm{I})$ is clearly observed in the urea gradient gel, but the separation of $\mathrm{N}$ and $\mathrm{I}$ is smeared, indicating a slow rate of conversion between the two forms (28). The second transition (I to U) observed by fluorescence is difficult to resolve in the gradient gel (see the inset) and suggests that the U to I transition is fast (28). The fluorescence experiments were also followed by measuring the emission wavelength maximum (Figure 2B). The results mirror-image the normalized total emission intensity data (Figure $2 \mathrm{~A}$ ) and indicate that the spectroscopic properties of $\mathrm{N}(\sim 330 \mathrm{~nm})$, $\mathrm{I}(\sim 343-347 \mathrm{~nm})$, and $\mathrm{U}(\sim 355)$ are distinct. The unfolding data by fluorescence were fit using a three-state model (26, 27 ), and the thermodynamic parameters are summarized in Table 1. Since both the WT and 2-FHis $\mathrm{PA}_{83}$ proteins exhibit similar denaturation profiles, we conclude that the global stability of the protein (to urea) has not been affected by incorporation of 2-FHis.

Effect of 2-FHis on the Stability of $P A_{83}$ to $\mathrm{pH}$. To assess the effect of $\mathrm{pH}$ on the structure and stability of $\mathrm{PA}_{83}$ and 2-FHisPA ${ }_{83}$, we compared the equilibrium stability as a function of $\mathrm{pH}$ by fluorescence and $\mathrm{CD}$ spectroscopy (Figures 3 and 4) $(23,35)$. Figure 3 shows the CD and fluorescence emission spectra (excitation at 280 and $295 \mathrm{~nm}$ ) of the WT and 2-FHis-labeled proteins as a function of $\mathrm{pH}$. At $\mathrm{pH}$ 5, the fluorescence peak maximum of the WT protein is redshifted to $345 \mathrm{~nm}$, and the CD spectrum exhibits a single minimum at $203 \mathrm{~nm}$, indicating partial unfolding. Very little change occurs in the 2-FHis-labeled protein with decreasing $\mathrm{pH}$, which suggests that 2-FHis incorporation prevents $\mathrm{pH}$ dependent unfolding (at least down to $\mathrm{pH} 4$-see Figure 4). We note from the CD spectra of the WT and 2-FHis-labeled proteins that they differ slightly in their secondary structurethe maxima and minima values are listed in Table 2, along with the calculated percent secondary structure content as determined using the program CDNN (24). The spectra indicate that the helical content increases for the 2-FHislabeled protein with a corresponding decrease in $\beta$-sheet content. The increase in helical content observed by $\mathrm{CD}$ is not due to changes in the oligomerization state of the protein as evidenced by analytical gel filtration (see the Supporting Information).

Figure 4 shows the effect of $\mathrm{pH}$ on the fluorescence of WT and 2-FHis-labeled proteins that spans the range from $\mathrm{pH} 8$ to 2, following either the peak maximum intensity (Figure 4A) or the emission wavelength maximum (Figure 4B). The data were fit using nonlinear least analysis to the Henderson-Hasselbalch equation to derive apparent $\mathrm{p} K_{\mathrm{a}}$ $\left(\mathrm{p} K_{\mathrm{app}}\right)$ values and are summarized in Table 1. Although both proteins are stable down to $\sim \mathrm{pH} 6$, the WT protein undergoes changes in both the wavelength and total intensity down to $\sim \mathrm{pH} 4.5$, with wavelength values comparable to the I state observed in the urea denaturation profile. The lower intensity values in the range of 6-4.5 (Figure 4A) may be due to aggregation even at these low $(0.4 \mu \mathrm{M})$ concentrations, since visible precipitation was observed at $\mathrm{pH} 5$ in the $\mathrm{CD}$ experiments, which dropped the soluble concentration from 17 to $10 \mu \mathrm{M}$. The aggregation was less for the 2-FHis-labeled protein, which may account for the intensity change observed 
A

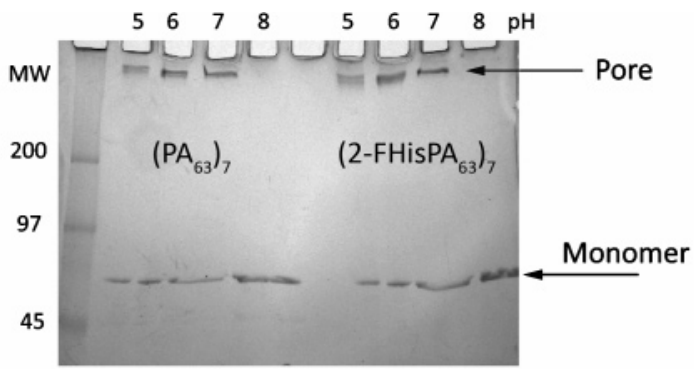

B

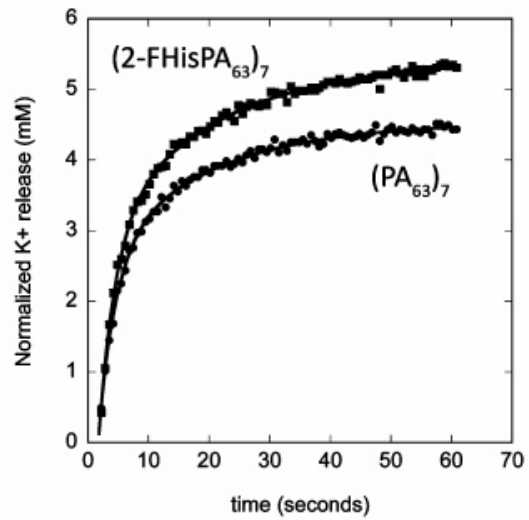

C

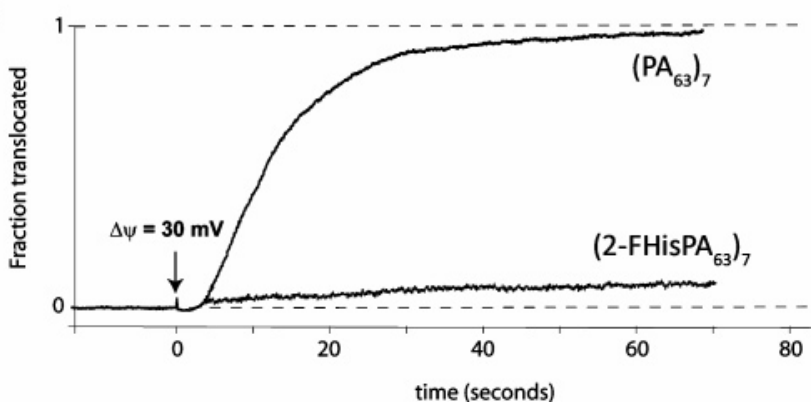

FiguRE 5: (A) Conversion of $\left(\mathrm{PA}_{63}\right)_{7}$ and $\left(2-\mathrm{FHisPA}_{63}\right)_{7}$ from a prepore $(\mathrm{pH} 8)$ to a pore state using an SDS-PAGE assay (5). Each lane contains $\sim 0.9 \mu \mathrm{M} \mathrm{PA}_{63}$. Buffers ( $350 \mathrm{mM}$ final) used were BisTris (pH 5 and 6) and HEPES (pH 7 and 8). (B) Rate of potassium release from DOPC liposomes over time as a result of PA pore insertion. Representative curves are shown for WT $(\bullet)$ and (2-FHisPA $\left.{ }_{63}\right)_{7}(\mathbf{\square})$ proteins. (C) Translocation of $\mathrm{LF}_{\mathrm{N}}$ shown as a function of time during macroscopic conductance measurements taken using a planar phospholipids bilayer system. Representative planar lipid bilayer macroscopic conductance records are shown for WT and (2-FHisPA $\left.{ }_{63}\right)_{7}$, and records are normalized as fraction translocated.

within the range of $\mathrm{pH} 5$ to 4 (Figure 4A). However, no change in the wavelength maximum occurred down to $\mathrm{pH} 4$ ( $\mathrm{p} K_{\text {app }}=3.6$ ), again showing that the 2-FHis-labeled protein is significantly more stable to $\mathrm{pH}(\sim 1-2$ units) than the WT protein.

Effect on Pore Formation by SDS-PAGE. In order to determine if the 2-FHis-labeled protein could carry out pore formation and translocation in vitro, we first determined the ability of the 2-FHis-labeled protein to form a pore as a function of $\mathrm{pH}$, using an SDS-PAGE assay (5). Upon formation of the 14-stranded $\beta$-barrel, the heptamer can no longer dissociate into individual $\mathrm{PA}_{63}$ monomers and, instead, is resistant to dissociation by SDS. Figure 5A shows the results for the prepore-pore conversion assayed by SDSPAGE as a function of $\mathrm{pH}$ and indicates that both proteins change to the pore conformation at similar $\mathrm{pH}$ values. Also, the structures of the two heptameric proteins are similar, since the far-UV CD spectra and the elution profiles from a Sephadex 200 gel filtration column of purified WT and (2FHisPA $\left._{63}\right)_{7}$ overlapped (see the Supporting Information). The data also suggest that the $\mathrm{pH}$-dependent increase in stability observed for the full-length 2-FHisPA 83 (Figures 3 and 4) does not attenuate pore formation for the $\left(2-\mathrm{FHisPA}_{63}\right)_{7}$ complex.

Effect of 2-FHis on Pore Insertion into Membranes. In addition to the SDS-PAGE assay, we investigated the ability of $\left(2-\mathrm{FHisPA}_{63}\right)_{7}$ to insert into membranes formed from DOPC by monitoring the release of $\mathrm{K}^{+}$from liposomes (29). Both protein complexes released $\mathrm{K}^{+}$from the liposomes at $\mathrm{pH} 5$, and release occurred with similar biphasic rate constants $\left(k_{1}=0.36 \pm 0.01 \mathrm{~s}^{-1}\right.$ (WT and 2-FHis); $k_{2}=0.056$ $\pm 0.001 \mathrm{~s}^{-1}$ (WT); $k_{2}=0.053 \pm 0.001 \mathrm{~s}^{-1}$ (2-FHis)) (Figure $5 \mathrm{~B})$.

Effect of 2-FHis on Translocation of LFn. To investigate the ability of $\left(2-\mathrm{FHisP}_{63}\right)_{7}$ to form a functional pore, we carried out translocation experiments in planar lipid bilayers using $\mathrm{LF}_{\mathrm{N}}$, the $\mathrm{N}$-terminal PA binding domain of $\mathrm{LF}$, comprising the first 263 amino acids (30). In planar lipid bilayers formed from $\mathrm{DPhPC}, \mathrm{LF}_{\mathrm{N}}$ bound to $\mathrm{WT}\left(\mathrm{PA}_{63}\right)_{7}$ and $\left(2-\mathrm{FHisPA}_{63}\right)_{7}$ pores, and the extent of blockage was similar for both complexes at $10 \mathrm{nM} \mathrm{LFn} \mathrm{(30).} \mathrm{For} \mathrm{the} \mathrm{WT} \mathrm{protein,}$ application of either a change in voltage to a positive membrane potential (from +20 to $+50 \mathrm{mV}, \Delta \Psi=+30$ $\mathrm{mV}$ ), or increasing the $\mathrm{pH}$ of the trans side, drives $\mathrm{LF}_{\mathrm{N}}$ through the pore (the cis side of the membrane is the side to which $\mathrm{PA}_{63}$ and $\mathrm{LF}_{\mathrm{N}}$ are added). The (2-FHisPA $\left.{ }_{63}\right)_{7}$ formed heptameric channels similar to the WT protein, and in the presence of $\mathrm{LF}_{\mathrm{N}}$ these channels were blocked, indicating that the binding surfaces necessary for entry of $\mathrm{LF}_{\mathrm{N}}$ into the pore were not perturbed. However, neither increasing the membrane potential to $+30 \mathrm{mV}$ (Figure 5C) nor raising the $\mathrm{pH}$ in the trans compartment (data not shown) was sufficient to drive $\mathrm{LF}_{\mathrm{N}}$ through these pores.

\section{DISCUSSION}

The pH-dependent conversion of anthrax PA from a heptameric prepore to a functional pore is a key step in the pathogenic mechanism of the toxin. Because the in vitro $\mathrm{pH}$ transition for pore formation occurs at $\sim 7$, and because of the prevalence of histidines in PA, particularly in domain 2 and the transmembrane loop, it has long been assumed that histidine protonation at reduced $\mathrm{pH}$ may trigger the preporeto-pore conversion. Here, we have labeled $\mathrm{PA}_{83}$ with 2-FHis, an isosteric analog of histidine with a $\mathrm{p} K_{\mathrm{a}}$ of $\sim 1$, in order to address the role of histidine protonation in pore formation and translocation. Although 2-FHisPA ${ }_{83}$ exhibited an increased stability to $\mathrm{pH}$ versus its unlabeled counterpart, (2FHisPA $\left._{63}\right)_{7}$ retained the ability to undergo pore formation at $\mathrm{pH}$ values similar to the WT protein. Aside from the $\mathrm{PA}_{20}$ domain of $\mathrm{PA}_{83}$, the crystal structures of $\mathrm{PA}_{83}$ and the heptameric $\left(\mathrm{PA}_{63}\right)_{7}$ are virtually identical $(5,36)$, including the placement of the histidine side chains and (presumably) their surrounding environments. Thus, we fully expected to observe an increase in $\mathrm{pH}$ stability of $\left(2-\mathrm{FHisPA}_{63}\right)_{7}$, consistent with what was observed for the full-length 2-FHisPA 83 . The fact that we did not, as evidenced by pore formation at comparable $\mathrm{pH}$, suggests that even though the tertiary structures of $\mathrm{PA}_{83}$ and $\left(\mathrm{PA}_{63}\right)_{7}$ are similar, $\mathrm{PA}_{20}$ 
influences the structure of $\mathrm{PA}_{63}$ to which it is bound (perhaps the dynamics of the protein structure) in a way that is not evident from examination of the crystal structures.

Importantly, our results show that both WT and 2-FHislabeled prepore proteins are able to form pores at nearly identical $\mathrm{pH}$ values and rates, indicating that the process of pore formation, at least in vitro, is independent of histidine protonation. Despite the formation of pores, however, the planar lipid bilayer experiments showed that for the (2$\left.\mathrm{FHisP}_{63}\right)_{7}$ protein, translocation of $\mathrm{LF}_{\mathrm{N}}$ is blocked and the pores are nonfunctional. The resulting block in translocation of $\mathrm{LF}_{\mathrm{N}}$ suggests that one or more of the histidine residues projected to line the toxin channel may be responsible for this effect and for the ineffectiveness of the 2-FHis-labeled protein in the cytotoxicity assay. Histidine residues that are known to be part of the transmembrane channel include His 304 and $310(10,11)$, which is in the loop between the domain $2 \beta 2-\beta 3$ strands, and His 299 and His 336. How 2-FHis labeling may affect these (or other) residues and their potential role in translocation is unclear.

We should note that the major difference between the planar bilayer experiments and the assay with $\mathrm{CHO}-\mathrm{K} 1$ cells is the presence of the cellular receptor, ANTXR2. The $\mathrm{pH}$ required for pore formation of $\left(\mathrm{PA}_{63}\right)_{7}$ is $\sim 1 \mathrm{pH}$ unit lower in the presence of $\operatorname{ANTXR} 2(5,29,37)$, and recent studies have shown that the receptor dissociates from PA upon pore formation so that dissociation may be a prerequisite to pore formation (37). Therefore, the possibility exists that in the context of the receptor, histidine protonation may be part of the mechanism required for $\mathrm{pH}$-dependent pore formation. A previous cysteine scanning mutagenesis study showed that almost every histidine (except for H304 and H253, which were not produced) could be individually replaced with cysteine without an effect on the ability to mediate cytotoxicity in macrophage cells (38). Although these studies could not rule out a synergistic effect of histidines far apart in the sequence (39), this and the study presented here suggests that other classes of titratable residues (probably Asp and $\mathrm{Glu}$ ) are involved in the $\mathrm{pH}$-dependent structural changes required for pore formation. Indeed, Sellman et al. (40) showed that Asp 425, which presumably resides, along with Phe 427 (30) and Asp 426 (41), within the lumen of the pore, when mutated to several different amino acids (Ala, Asn, Lys, and Glu) could not form an SDS-resistant pore in vitro at $\mathrm{pH} 5$ and, likewise, was nonfunctional in translocation and in cytotoxicity assays. Although no conclusions were drawn from these experiments on the role of Asp 425, the data presented here point to this or other residues as the $\mathrm{pH}$ sensor for pore formation.

\section{ACKNOWLEDGMENT}

We thank Dr. Carl Frieden for comments on the manuscript and Mrs. Haiying Zhou and Mrs. Maheshinie Rajapaksha for help in purifying proteins and carrying out SDSPAGE analyses. We especially thank Dr. Todd Williams and Dr. Nadezhda Galeva at the University of Kansas Mass Spectrometry facility for the FT mass spectrometry analysis.

\section{SUPPORTING INFORMATION AVAILABLE}

FT and LC mass spectrometry and analytical gel filtration of WT and 2-FHisPA 83 and gel filtration and far-UV circular dichroism spectra of WT and 2-FHis $\left(\mathrm{PA}_{63}\right)_{7}$. This material is available free of charge via the Internet at http:// pubs.acs.org.

\section{REFERENCES}

1. Collier, R. J., and Young, J. A. T. (2003) Anthrax toxin, Annu. Rev. Cell Dev. Biol. 19, 45-70.

2. Bradley, K. A., Mogridge, J., Mourez, M., Collier, R. J., and Young, J. A. T. (2001) Identification of the cellular receptor for anthrax toxin, Nature 414, 225-229.

3. Bell, S. E., Mavila, A., Salazar, R., Bayless, K. J., Kanagala, S., Maxwell, S. A., and Davis, G. E. (2001) Differential gene expression during capillary morphogenesis in 3-D collagen matrices: regulated expression of genes involved in basement membrane matrix assembly, cell cycle progression, cellular differentiation and G-protein signaling, J. Cell Sci. 114, 27552773.

4. Scobie, H. M., Rainey, G. J. A., Bradley, K. A., and Young, J. A. (2003) Human capillary morphogenesis protein 2 functions as an anthrax toxin receptor, Proc. Natl. Acad. Sci. U.S.A. 100, 51705174.

5. Lacy, D. B., Wigelsworth, D. J., Melnyk, R. A., Harrison, S. C., and Collier, R. J. (2004) Structure of heptameric protective antigen bound to an anthrax toxin receptor: a role for receptor in $\mathrm{pH}$ dependent pore formation, Proc. Natl. Acad. Sci. U.S.A. 101, 13147-13151.

6. Lacy, D. B., Lin, H. C., Melnyk, R. A., Schueler-Furman, O., Reither, L., Cunningham, K., Baker, D., and Collier, R. J. (2005) A model of anthrax toxin lethal factor bound to protective antigen, Proc. Natl. Acad. Sci U.S.A. 102, 16409-16414

7. Melnyk, R. A., Hewitt, K. M., Lacy, D. B., Lin, H. C., Gessner, C. R., Li, S., Woods, V. L., Jr., and Collier, R. J. (2006) Structural determinants for the binding of anthrax lethal factor to oligomeric protective antigen, J. Biol. Chem. 281, 1630-1635.

8. Abrami, L., Liu, S., Cosson, P., Leppla, S. H., and van der Goot, F. G. (2003) Anthrax toxin triggers endocytosis of its receptor via a lipid raft-mediated clathrin-dependent process, J. Cell Biol. $160,321-328$.

9. Wei, W., Lu, Q., Chaudry, G. J., Leppla, S. H., and Cohen, S. N. (2006) The LDL-receptor-related protein LRP6 mediates internalization and lethality of anthrax toxin, Cell 124, 1141-1154.

10. Nassi, S., Collier, R. J., and Finkelstein, A. (2002) PA63 channel of anthrax toxin: an extended $\beta$-barrel, Biochemistry $41,1440-$ 1450 .

11. Benson, E. L., Huynh, P. D., Finkelstein, A., and Collier, R. J. (1998) Identification of residues lining the anthrax protective antigen channel, Biochemistry 37, 3941-3948.

12. Miller, C. J., Elliott, J. L., and Collier, R. J. (1999) Anthrax protective antigen: prepore to pore conversion, Biochemistry 38 , 10432-10441.

13. Blaustein, R. O., Koehler, T. M., Collier, R. J., and Finkelstein, A. (1989) Anthrax toxin: channel-forming activity of protective antigen in planar phospholipid bilayers, Proc. Natl. Acad. Sci. U.S.A. 86, 2209-2213.

14. Takahashi, T., Nakamura, H., and Wada, A. (1992) Electrostatic forces in two lysozymes: calculations and measurement of histidine pKa values, Biopolymers 32, 897-909.

15. Singer, A. U., and Forman-Kay, J. D. (1997) pH titration studies of an SH2-domain phosphopeptide complex: unusual histidine and phosphate pKa values, Protein Sci. 6, 1910-1919.

16. Santelli, E., Bankston, L. A., Leppla, S. H., and Liddington, R. C. (2004) Crystal structure of a complex between anthrax toxin and its host cell receptor, Nature 430, 905-908.

17. Eichler, J. F., Cramer, J. C., Kirk, K. L., and Bann, J. G. (2005) Biosynthetic incorporation of fluorohistidine into proteins in E. coli: a new probe of macromolecular structure, ChemBioChem $6,1-4$.

18. Kirk, K. L., and Cohen, L. A. (1973) Photochemistry of diazonium salts. I. Synthesis of 4-fluoroimidazoles, 4-fluorohistamine and 4-fluorohistidine, J. Am. Chem. Soc. 95, 4619-4624.

19. Kirk, K. L., Nagai, W., and Cohen, L. A. (1973) Photochemistry of diazonium salts. II. Synthesis of 2-fluoro-L-histidine and 2-fluorohistamine, and the halogen lability of 2-fluoroimidazoles, J. Am. Chem. Soc. 95, 8389-8392. 
20. Yeh, H. J. C., Kirk, K. L., and Cohen, L. A., and Cohen, J. S. (1975) ${ }^{19} \mathrm{~F}$ and ${ }^{1} \mathrm{H}$ nuclear magnetic resonance studies of ringfluorinated imidazoles and histidines, J. Chem. Soc., Perkin Trans. 2, 928-934.

21. Wigelsworth, D. J., Krantz, B. A., Christensen, K. A., Lacy, D. B., Juris, S. J., and Collier, R. J. (2004) Binding stoichiometry and kinetics of the interaction of a human anthrax toxin receptor, CMG2, with protective antigen, J. Biol. Chem. 279, 23349-23356.

22. Frieden, C., Hoeltzli, S. D., and Bann, J. G. (2004) The preparation of 19F-labeled proteins for NMR studies, Methods Enzymol. 380, 400-415.

23. Pace, C. N., Vajdos, F., Fee, L., Grimsley, G., and Gray, T. (1995) How to measure and predict the molar absorption coefficient of a protein, Protein Sci. 11, 2411-2423.

24. Bohm, G., Muhr, R., and Jaenicke, R. (1992) Quantitative analysis of protein for UV circular dichroism spectra by neural networks, Protein Engineering 5, 191-195.

25. Pace, C. N., and Scholtz, J. M. (1997) in Protein Structure: A Practical Approach (Creighton, T. E., Ed.) 2nd ed., Oxford University Press, Oxford, U.K.

26. Barrick, D., and Baldwin, R. L. (1993) Three-state analysis of sperm whale apomyoglobin folding, Biochemistry 32, 3790-3796.

27. Tan, P. H., Sandmaier, B. M., and Stayton, P. S. (1998) Contributions of a highly conserved VH/VL hydrogen bonding interaction to $\mathrm{scFv}$ folding stability and refolding efficiency, Biophys. J. 75, 1473-1482.

28. Goldenberg, D. P. (1997) in Protein Structure: A Practical Approach (Creighton, T. E., Ed.) 2nd ed., Oxford University Press, Oxford, U.K.

29. Sun, J., Vernier, G., Wigelsworth, D. J., and Collier, R. J. (2007) Insertion of anthrax protective antigen into liposomal membranes: effects of a receptor, J. Biol. Chem. 282, 1059-1065.

30. Krantz, B. A., Melnyk, R. A., Zhang, S., Juris, S. J., Lacy, D. B., Wu, Z., Finkelstein, A., and Collier, R. J. (2005) A phenylalanine clamp catalyzes protein translocation through the anthrax toxin pore, Science 309, 777-781.

31. Sellman, B. R., Mourez, M., and Collier, R. J. (2001) Dominantnegative mutants of a toxin subunit: an approach to therapy of anthrax, Science 292, 695-697.

32. Yan, M., and Collier, R. J. (2003) Characterization of dominantnegative forms of anthrax protective antigen, Mol. Med. 9, 4651 .
33. Gupta, P. K., Chandra, H., Gaur, R., Kurupati, R. K., Chowdhury, S., Tandon, V., Singh, Y., and Maithal, K. (2003) Conformational fluctuations in anthrax protective antigen: a possible role of calcium in the folding pathway of the protein, FEBS Lett. 554, $505-510$.

34. Christensen, K. A., Krantz, B. A., Melnyk, R. A., and Collier, R. J. (2005) Interaction of the $20 \mathrm{kDa}$ and $63 \mathrm{kDa}$ fragments of anthrax protective antigen: kinetics and thermodynamics, Biochemistry 44, 1047-1053.

35. Barrick, D., Hughson, F. M., and Baldwin, R. L. (1994) Molecular mechanisms of acid denaturation. The role of histidine residues in the partial unfolding of apomyoglobin, J. Mol. Biol. 237, 588601.

36. Petosa, C., Collier, R. J., Klimpel, K. R., Leppla, S. H., and Liddington, R. C. (2004) Crystal structure of the anthrax toxin protective antigen, Nature 430, 905-908.

37. Rainey, G. J., Wigelsworth, D. J., Ryan, P. L., Scobie, H. M., Collier, R. J., and Young, J. A. (2005) Receptor-specific requirements for anthrax toxin delivery into cells, Proc. Natl. Acad. Sci. U.S.A. 102, 13278-13283.

38. Mourez, M., Yan, M., Lacy, D. B., Dillon, L., Bentsen, L., Marpoe, A., Maurin, C., Hotze, E., Wigelsworth, D., Pimental, R. A., Ballard, J. D., Collier, R. J., and Tweten, R. K. (2003) Mapping dominant-negative mutations of anthrax protective antigen by scanning mutagenesis, Proc. Natl. Acad. Sci. U.S.A. 100, 1380313808.

39. Perier, A., Chassaing, A., Raffestin, S., Pichard, S., Masella, M., Menez, A., Forge, V., Chenal, A., and Gillet, D. (2007) Concerted protonation of key histidines triggers membrane interaction of the diphtheria toxin T domain, J. Biol. Chem. 282, 24239-24245.

40. Sellman, B. R., Nassi, S., and Collier, R. J. (2001) Point mutations in anthrax protective antigen that block translocation, J. Biol. Chem. 276, 8371-8376.

41. Melnyk, R. A., and Collier, R. J. (2006) A loop network within the anthrax toxin pore positions the phenylalanine clamp in an active conformation, Proc. Natl. Acad. Sci. U.S.A. 103, 9802-9807.

BI701763Z 